\title{
In Vitro Fertilization and Vasa Previa: A Report of Two Cases
}

\section{Fertilização in vitro e vasa previa: relato de dois casos}

\author{
Ana Lúcia Isotton ${ }^{1,20}$ Cristiano Caetano Salazar ${ }^{2,3}$ Cleisson Fábio Andrioli Peralta ${ }^{4}$ \\ Juliana Moysés Leite Abdalla ${ }^{4}$ Janete Vettorazzi 1,2,3,5 \\ ${ }^{1}$ Service of Fetal Medicine, Medicina Fetal Porto Alegre, Porto Alegre, \\ RS, Brazil \\ ${ }^{2}$ Service of Gynecology and Obstetrics, Hospital Moinhos de Vento, \\ Address for correspondence Ana Lúcia Isotton, MD, Av. Cristóvão \\ Colombo, 2948/908, 90560-002, Porto Alegre, RS, Brazil \\ Porto Alegre, RS, Brazil \\ 3 Service of Gynecology and Obstetrics, Hospital de Clínicas de Porto \\ Alegre, Porto Alegre, RS, Brazil \\ ${ }^{4}$ Service of Fetal Medicine, Gestar Centro de Medicina Fetal, São \\ Paulo, SP, Brazil \\ 5 Postgraduation Program in Health Sciences, Gynecology and Obstetrics, \\ Universidade Federal do Rio Grande do Sul, Porto Alegre, Brazil \\ (e-mail: anaisotton@terra.com.br). \\ Rev Bras Ginecol Obstet 2019;41:348-351.
}

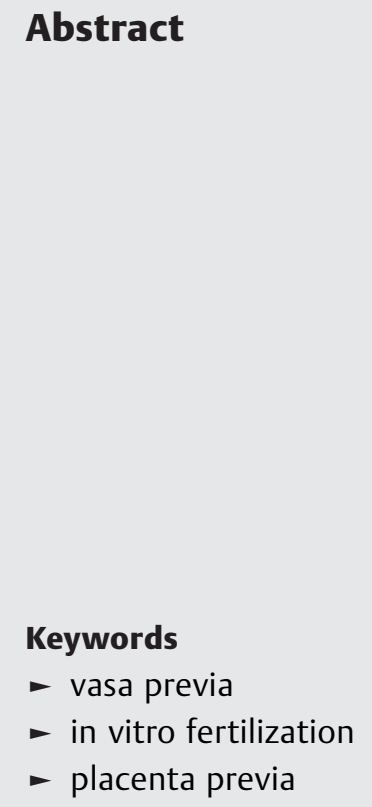

Resumo
Vasa previa (VP) is a dangerous obstetric condition associated with perinatal mortality and morbidity. In vitro fertilization (IVF) is a risk factor for VP due to the high incidence of abnormal placentation. The diagnosis should be made prenatally, because fetal mortality can be extremely high. We report two cases to demonstrate the accuracy of transvaginal ultrasound in the prenatal diagnosis of VP. A 40-year-old primiparous Caucasian woman with IVF pregnancy was diagnosed with VP at 29 weeks of gestation and was hospitalized for observation at 31 weeks of gestation. She delivered a male newborn weighing $2,380 \mathrm{~g}$, with an Apgar score of 10 at 5 minutes, by elective cesarean section at 34 weeks +4 days of gestation, without complications. A 36-yearold primiparous Caucasian woman with IVF pregnancy was diagnosed with placenta previa, bilobed placenta increta and VP. The cord insertion was velamentous. She was hospitalized for observation at 26 weeks of gestation. She delivered a female newborn weighing 2,140 g, with an Apgar score of 9 at 5 minutes, by emergency cesarean section at 33 weeks +4 days of gestation due to vaginal bleeding. The prenatal diagnosis of VP was associated with a favorable outcome in the two cases, supporting previous observations that IVF is a risk factor for VP and that all IVF pregnancies should be screened by transvaginal ultrasound.

Vasa previa (VP) é uma condição obstétrica perigosa associada a mortalidade e morbidade perinatais. Fertilização in vitro (FIV) é um fator de risco para VP devido à alta incidência de placentação anormal. O diagnóstico deve ser realizado no período

\footnotetext{
(D)Ana Lúcia Isotton's ORCID is https://orcid.org/0000-0003-3466043X.
}

received

September 25, 2018

accepted

January 28, 2019
DOI https://doi.org/ 10.1055/s-0039-1683354. ISSN 0100-7203.
Copyright $\odot 2019$ by Thieme Revinter Publicações Ltda, Rio de Janeiro, Brazil
License terms

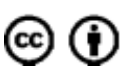




\section{Palavras-chave \\ - vasa previa \\ - fertilização in vitro \\ - placenta prévia}

pré-natal, pois a possibilidade de mortalidade fetal é extremamente elevada. Relatamos dois casos para demonstrar a acurácia da ultrassonografia transvaginal no diagnóstico pré-natal de VP. Mulher caucasiana, primigesta, de 40 anos, submetida a FIV, foi diagnosticada com VP na 29a semana de gestação e hospitalizada para observação na $31^{\text {a }}$ semana de gestação. A paciente foi submetida à cesariana eletiva com 34 semanas e 4 dias, sem complicações, com recém-nascido do sexo masculino, pesando $2.380 \mathrm{~g}$, e com Apgar de $10 \mathrm{no} 5^{\circ}$ minuto. Mulher caucasiana, primigesta, de 36 anos, subetida a FIV, foi diagnosticada com placenta prévia, placenta bilobada, acretismo placentário e VP. Cordão umbilical com inserção velamentosa. A paciente foi hospitalizada para observação na $26^{a}$ semana de gestação. Foi submetida à cesariana de emergência com 33 semanas e 4 dias por sangramento vaginal. O recém nascido do sexo feminino pesou $2.140 \mathrm{~g}$, com Apgar de 9 no $5^{\circ}$ minuto. O diagnóstico de VP no período pré-natal associou-se a um desfecho favorável nos dois casos, corroborando observações anteriores de que a FIV é um fator de risco para VP e de que todas as gestações por FIV deveriam ser avaliadas por ultrassonografia transvaginal.

\section{Background}

Vasa previa (VP) is a dangerous obstetric condition associated with perinatal mortality and morbidity, with an incidence of $\sim$ 1 per 2,500 deliveries. In vitro fertilization (IVF) is considered a risk factor for VP due to the high incidence of abnormal placentation. Other risk factors include low-lying placenta or placenta previa, bilobed or succenturiate-lobed placenta, and multiple gestations. The diagnosis should be made prenatally, because fetal mortality can be extremely high.

\section{Case Description}

\section{Case 1}

A 40-year-old primiparous Caucasian woman with placenta previa and pregnancy obtained after IVF, without prenatal complications, was diagnosed with VP at 29 weeks of gestation. The ultrasound scan revealed a fetal blood vessel traversing across the cervical os, suggestive of VP ( patient was admitted to the hospital for observation at 31 weeks of gestation and received corticosteroids. Fetal monitoring and

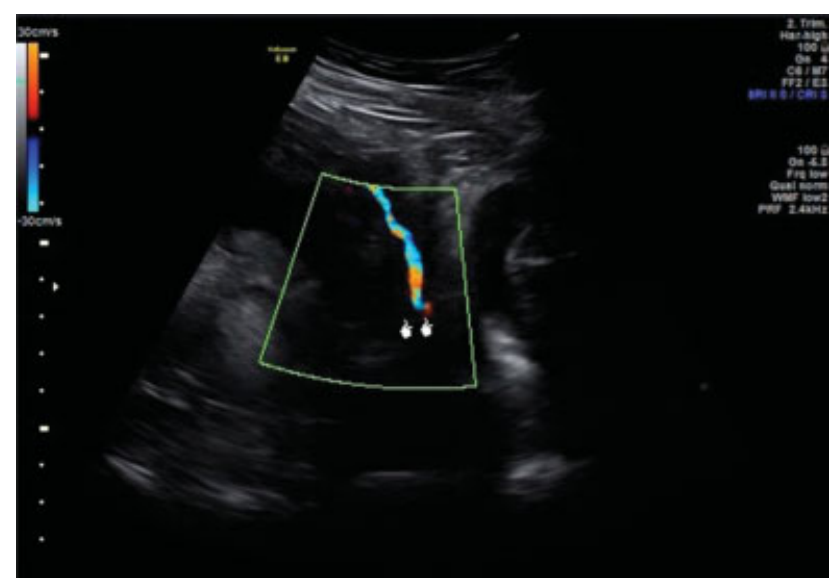

Fig. 1 Abdominal ultrasound with high-definition color-flow Doppler imaging showing a fetal blood vessel traversing across the cervical os, suggestive of vasa previa (VP). uterine contraction assessment were performed daily. The estimated fetal weight was always at the $50^{\text {th }}$ percentile. She delivered a male infant weighing 2,380 g, with an Apgar score of 10 at 5 minutes, by elective cesarean section at 34 weeks +4 days of gestation without any intraoperative complications. The newborn was referred to the neonatal intensive care unit (ICU) and remained there for 2 days. He received continuous positive airway pressure (CPAP) for 12 hours and progressed well with exclusive breastfeeding.

\section{Case 2}

A 36-year-old primiparous Caucasian woman with pregnancy obtained after IVF was diagnosed with placenta previa, bilobed placenta increta and VP at 23 weeks of gestation. The cord insertion was velamentous (-Figs. 3, 4, and 5). She was admitted to the hospital for observation at 26 weeks of gestation and received corticosteroids at 30 weeks of gestation. Oral nifedipine was administered because uterine contractions began at 30 weeks of gestation. The screening test was positive for gestational diabetes mellitus, and the patient was placed on dietary therapy. She delivered a female infant

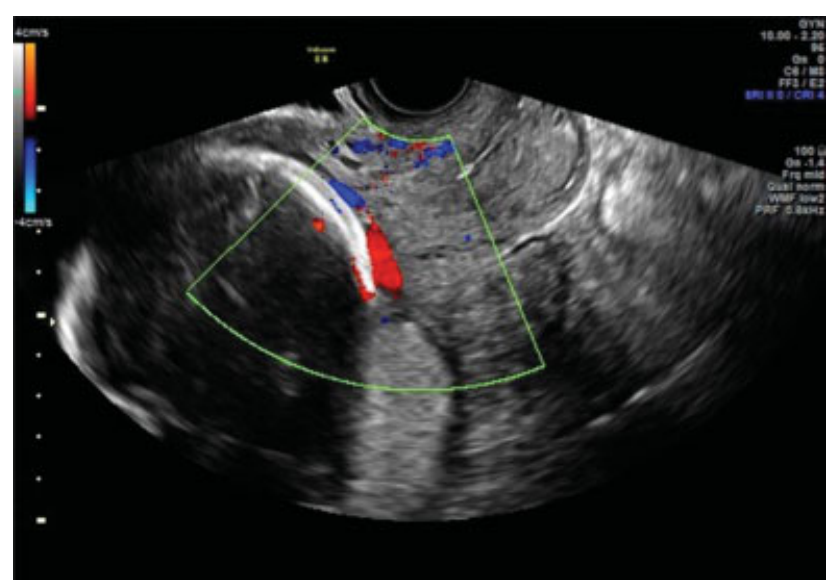

Fig. 2 Transvaginal ultrasound with high-definition color-flow Doppler imaging of vasa previa (VP). 


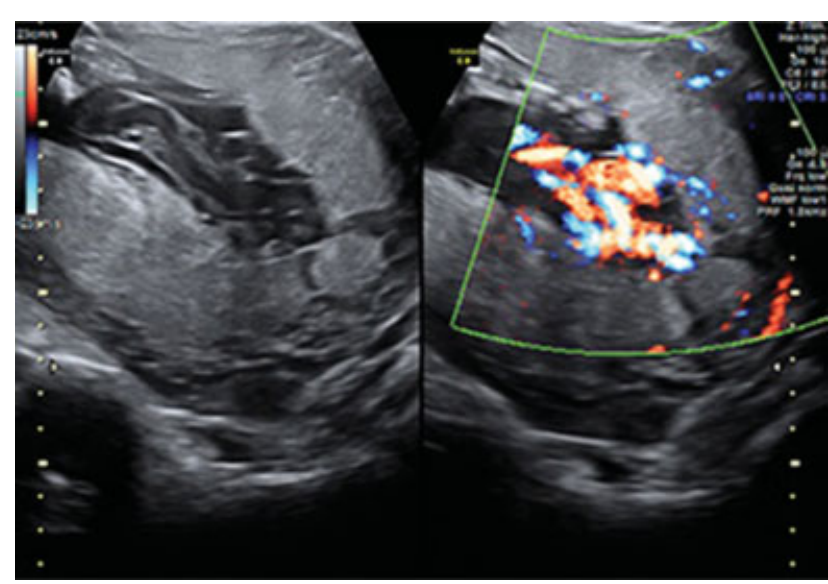

Fig. 3 High-definition color-flow Doppler imaging showing bilobed placenta previa and velamentous insertion of the umbilical cord.

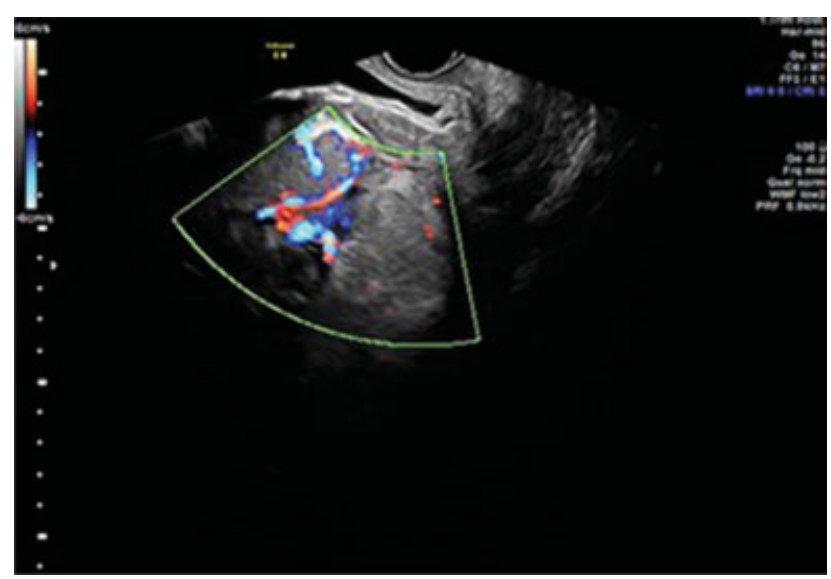

Fig. 4 Transvaginal ultrasound with high-definition color-flow Doppler imaging of vasa previa (VP).

weighing 2,140 g, with an Apgar score of 9 at 5 minutes, by emergency cesarean section at 33 weeks +4 days of gestation due to vaginal bleeding. After delivery, a hysterectomy was performed without removing the placenta. The newborn was referred to the neonatal ICU and remained there for 16 days on CPAP. The newborn progressed well with exclusive breastfeeding.

\section{Discussion}

Vasa previa is a complication of pregnancy in which fetal blood vessels lie outside the chorionic plate, in close proximity to the internal cervical os. These vessels may rupture with resultant fetal hemorrhage, exsanguination, or even death. ${ }^{1}$

Approximately 1 per 2,500 deliveries are complicated by VP, and the major risk factors are velamentous cord insertion and succenturiate placental lobe or bilobed placenta. ${ }^{2,3}$ Approximately $60 \%$ of the women with VP at delivery had a placenta previa or a low-lying placenta identified during the second trimester ultrasound examination. ${ }^{4}$ Another risk factor is IVF, which may increase the risk of VP to $\sim 1$ per 250 deliveries. ${ }^{5,6}$

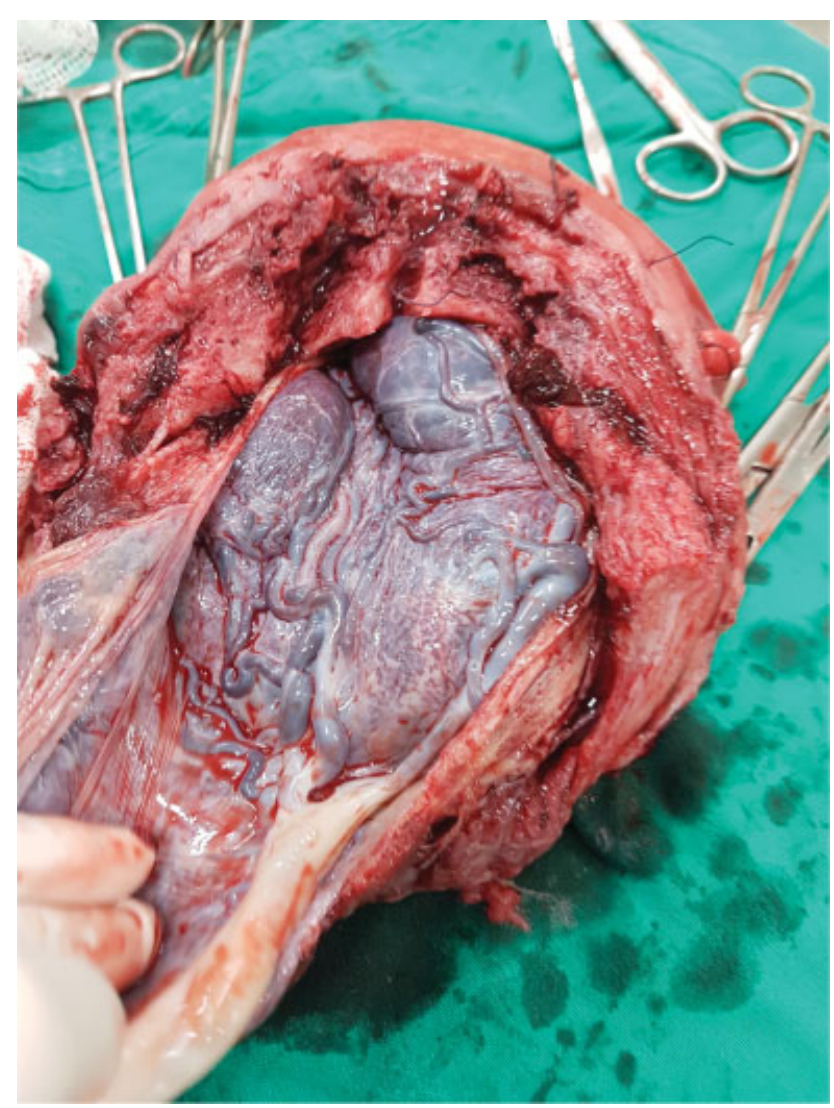

Fig. 5 Macroscopic image of the uterus and placenta with a velamentous insertion of the umbilical cord.

The present report supports previous observations that IVF is a risk factor for VP, and transvaginal ultrasound screening for VP appears to be most cost-effective when performed among IVF pregnancies. ${ }^{7}$ Jauniaux et $\mathrm{al}^{8}$ found an incidence of bilobed and succenturiate-lobed placenta of $22 \%$ in the IVF group compared with $6 \%$ in the control group. Abnormal umbilical cord insertion with normal placental morphology has been associated with IVF. Englert et $\mathrm{al}^{9}$ found a marginal insertion of the umbilical cord in $15 \%$ of the cases, and velamentous insertion in $14 \%$ of the cases, more frequently than in the general obstetric population. Romundstad et al ${ }^{10}$ reported that the risk of placenta previa was 3-fold higher in pregnancies following assisted fertilization (odds ratio $[\mathrm{OR}]=2.9 ; 95 \%$ confidence interval $[\mathrm{CI}]$ : 1.4-6.1) compared with naturally conceived pregnancies.

High estradiol concentrations at the time of implantation may impair the endometrial response to trophoblast invasion, leading to abnormal placentation. ${ }^{11-13}$ Farhi et al ${ }^{11}$ found that a concentration $>10,000 \mathrm{pmol} / \mathrm{L}$ led to significantly more complications related to abnormal placentation.

The diagnosis of VP by ultrasound combined with color Doppler imaging can be made during the routine examination of the placenta and of the lower uterine segment, with a detection rate of $93 \%$ and a specificity of $99 \%{ }^{14}$ Transvaginal ultrasound is extremely important for an accurate diagnosis, and cases that are not diagnosed prenatally are often associated with serious complications, such as fetal death, low Apgar scores, and severe anemia. ${ }^{14,15}$ 


\section{Conclusion}

Vasa previa is strongly associated with abnormal placentation in the second trimester and can be accurately diagnosed by ultrasound. In the two cases reported here, the prenatal diagnosis of VP was associated with a favorable outcome.

\section{Conflicts of Interest}

The authors have no conflicts of interest to declare.

\section{References}

1 Society of Maternal-Fetal (SMFM) Publications Committee. Sinkey RG, Odibo AO, Dashe JS. \#37: Diagnosis and management of vasa previa. Am J Obstet Gynecol 2015;213:615-619. Doi: 10.1016/j.ajog.2015.08.031

2 Catanzarite V, Maida C, Thomas W, Mendoza A, Stanco L, Piacquadio KM. Prenatal sonographic diagnosis of vasa previa: ultrasound findings and obstetric outcome in ten cases. Ultrasound Obstet Gynecol 2001;18(02):109-115. Doi: 10.1046/j.14 69-0705.2001.00448.x

3 Hasegawa J, Farina A, Nakamura M, et al. Analysis of the ultrasonographic findings predictive of vasa previa. Prenat Diagn 2010;30(12-13):1121-1125. Doi: 10.1002/pd.2618

4 Bronsteen R, Whitten A, Balasubramanian M, et al. Vasa previa: clinical presentations, outcomes, and implications for management. Obstet Gynecol 2013;122(2 Pt 1):352-357. Doi: 10.1097/ AOG.0b013e31829cac58

5 Baulies S, Maiz N, Muñoz A, Torrents M, Echevarría M, Serra B. Prenatal ultrasound diagnosis of vasa praevia and analysis of risk factors. Prenat Diagn 2007;27(07):595-599. Doi: 10.1002/pd.1753

6 Pirtea LC, Grigoraş D, Sas I, et al. In vitro fertilization represents a risk factor for vasa praevia. Rom J Morphol Embryol 2016;57(2, Suppl)627-632
7 Sinkey RG, Odibo AO. Vasa previa screening strategies: decision and cost-effectiveness analysis. Ultrasound Obstet Gynecol 2018; 52(04):522-529. Doi: 10.1002/uog.19098

8 Jauniaux E, Englert Y, Vanesse M, Hiden M, Wilkin P. Pathologic features of placentas from singleton pregnancies obtained by in vitro fertilization and embryo transfer. Obstet Gynecol 1990; 76(01):61-64

9 Englert Y, Imbert MC, Van Rosendael E, et al. Morphological anomalies in the placentae of IVF pregnancies: preliminary report of a multicentric study. Hum Reprod 1987;2(02):155-157. Doi: 10.1093/oxfordjournals.humrep.a136500

10 Romundstad LB, Romundstad PR, Sunde A, von Düring V, Skjaerven $R$, Vatten $L J$. Increased risk of placenta previa in pregnancies following IVF/ICSI; a comparison of ART and non-ART pregnancies in the same mother. Hum Reprod 2006;21(09):2353-2358. Doi: 10.1093/humrep/del153

11 Farhi J, Ben-Haroush A, Andrawus N, et al. High serum oestradiol concentrations in IVF cycles increase the risk of pregnancy complications related to abnormal placentation. Reprod Biomed Online 2010;21(03):331-337. Doi: 10.1016/j.rbmo.2010.04.022

12 Simón C, Cano F, Valbuena D, Remohí J, Pellicer A. Clinical evidence for a detrimental effect on uterine receptivity of high serum oestradiol concentrations in high and normal responder patients. Hum Reprod 1995;10(09):2432-2437. Doi: 10.1093/oxfordjournals.humrep.a136313

13 Healy DL, Breheny S, Halliday J, et al. Prevalence and risk factors for obstetric haemorrhage in 6730 singleton births after assisted reproductive technology in Victoria Australia. Hum Reprod 2010; 25(01):265-274. Doi: 10.1093/humrep/dep376

14 Ruiter L, Kok N, Limpens J, et al. Systematic review of accuracy of ultrasound in the diagnosis of vasa previa. Ultrasound Obstet Gynecol 2015;45(05):516-522. Doi: 10.1002/ uog. 14752

15 Sullivan EA, Javid N, Duncombe G, et al. Vasa previa diagnosis, clinical practice, and outcomes in Australia. Obstet Gynecol 2017; 130(03):591-598. Doi: 10.1097/AOG.0000000000002198 